\title{
Multidimensional Scaling Analysis: An Application to Positioning Cosmetic Brands
}

\author{
Wiwit Pura Nurmayanti ${ }^{*}$, Siti Arni Wulandya ${ }^{2}$, and Abdul Rahim ${ }^{3}$ \\ ${ }^{123}$ Universitas Hamzanwadi, Selong, Indonesia, \\ ${ }^{12}$ Dep. of Statistics, Faculty of Mathematics and Natural Sciences, Universitas Hamzanwadi, Selong, Indonesia, \\ ${ }^{3}$ Dep. of Pharmacy, Faculty of Health, Universitas Hamzanwadi, Selong, Indonesia, \\ *Corresponding author. Email: wiwitpura.n@hamzanwadi.ac.id
}

\begin{abstract}
Positioning is one of the most powerful marketing concepts. The importance of knowing the position of the product because the positioning is part of the broader marketing strategy which includes three basic decision levels, namely segmentation, targeting and positioning. In statistics, a method that can describe the positioning is Multidimensional Scaling (MDS). The purpose of multidimensional scaling is to provide a visual description of the proximity pattern as similarities or distances between a set of objects. Cosmetic products always get the attention of women including students as consumers who tend to always follow lifestyle trends that involve physical appearance and beauty. This study finds out the position of Wardah cosmetics compared to nine other brands on the market based on the attributes that influence consumers' perceptions in buying cosmetics. The observed variables in this research are attributes of cosmetic products which are: brand, packaging, price, and ingredients. By using the MDS method, the results show that Wardah cosmetics are in the positive zone when viewed from packaging and safe material and suitable for the skin, but Wardah is in the negative zone when viewed from brand popularity and inexpensive.
\end{abstract}

Keywords: Positioning, Multidimensional Scaling, Multivariate, Cosmetic, Wardah

\section{INTRODUCTION}

Positioning is a variety of ways to design a product and a brand so that it will provide a unique position to consumers. The purpose of market positioning is to create a value proposition that is appropriate from the point of view of the consumer and the reason consumers buy the product in question. Positioning is an activity to design a product and marketing mix to create a certain impression on the minds of consumers (Huang \& $\mathrm{Ku}, 2016$ ). In addition, positioning is the third stage after the company has determined its market segmentation and target market. The views and thoughts of consumers will get information about a product and service offered, and consumers certainly cannot remember about product specifications when the need for a product arises. Consumers only remember products based on product position from what they hear and think, so advertising and brand positioning are needed (Gengler \& Mulvey, 2017). In statistics, the method that can describe positioning is Multidimensional Scaling.

The purpose of multidimensional scaling is to provide a visual description of the proximity pattern as similarities or distances between a set of objects (Mair, 2018), (Borg, Groenen, \& Mair, 2018). MDS is a multivariate analysis that shows the relationship between several objects in a multidimensional room based on the respondent's assessment of the similarity of these objects (Bai, Bai, Latecki, \& Tian, 2016). MDS analysis is useful for evaluating brand positioning, measuring company image, market segmentation, advertising effectiveness, price analysis, cooperation network decisions, and new product development. The perceptual map in MDS shows opportunities for new product placements. In addition, it is also to evaluate new product concepts and existing brands based on determining how customers perceive/ understand new concepts. (Nguyen \& Holmes, 2019), (Liu, Maljovec, Wang, Bremer, \& Pascucci, 2016) .

According to the Minister of Industry, Airlangga Hartanto in Investor Daily Media stated that Indonesia has 760 cosmetics industries(Kemenperin, 2018). Some cosmetics industry there are several cosmetic brands whose names are familiar by people community such as Make Over, L'Oreal, Oriflame, Mustika Ratu, Sariayu, Ponds, Viva, Wardah, La Tulipe, Mybelline, etc. Wardah is one cosmetic that is relatively new compared to nine other cosmetics, Wardah started pioneering in 1995, but the public is familiar a lot of this cosmetics. The cosmetics that are carried by Nurhayati are the first cosmetics to get halal certificate from the MUI and have received the International Halal Award from the World Halal Council for pioneering halal cosmetics in the world. 
Cosmetic products always get the attention of women, female students no exception as consumers who tend to always follow the lifestyle trends that involve physical appearance and beauty, because everything related to physical appearances and beauty becomes the main requirement in appearance) (Elias, Gill, \& Scharff, 2017), (Couteau \& Coiffard, 2016). This study finds out the position of Wardah cosmetics compared to nine other brands on the market based on the attributes that influence consumers' perceptions in buying cosmetics. We conducted this research at one of the best private universities in West Nusa Tenggara (NTB) that is Hamzanwadi University.

\section{METHOD}

The data used in this study are primary data and secondary data. Primary data were taken from questionnaires given to female students who were selected as samples. The sampling technique used is Stratified Random Sampling, using a 5\% sampling error and a $95 \%$ confidence interval, then the required sample size is 300 from all major at Hamzanwadi University. While secondary data that is data obtained from the number of students, in academic year 2017-2018. The collected Data starts from May 21 until June 4, 2018).

The observed variables in this research are attributes of cosmetic products which are: brand, packaging, price, and ingredients. The operational definition of the variable is:

- A brand is a name, term, design, symbol or any feature that identifies one seller's product or service as distinct from those of other sellers (Brahmbhatt \& Shah, 2017), (Goncharova, Solosichenko, \& Merzlyakova, 2019);

- Packaging is a product put on the market made of any materials, intended for storing, protection, transport, delivering or presentation of products, from raw materials to processed goods (Wyrwa \& Barska, 2017), (de Koeijer, Wever, \& Henseler, 2017);

- Ingredients: Ingredients or mixtures of ingredients derived from natural or synthetic ingredients which are cosmetic components (safe and suitable for the skin) (Safford et al., 2017);

Data analysis methods used in this study are Descriptive Analysis and Multidimensional Scaling (MDS). The stages of analysis in this research are:

- Do descriptive analysis data to observe the general overview;

- Conducted Multidimensional Scaling to transform the respondent judgments of similarity a brand into distance represented in multidimensional space.

\section{RESULTS AND DISCUSSION}

\section{Descriptive Statistics}

Based on the results of descriptive analysis obtained information as follows:

Figure 1 showed the majority Hamzanwadi University of female students is familiar to the ten cosmetic brands on the market, so there are indicated that cosmetic products from various brands have get great attention from the public, especially among female students. This is a positive sign for the company because the products they market can be accepted by the public, but this is also a challenge for cosmetics manufacturers because the more brands on the market have an impact the greater the opportunity for consumers, especially college students to choose the products they like and opportunities try to switch to other brands is quite large.

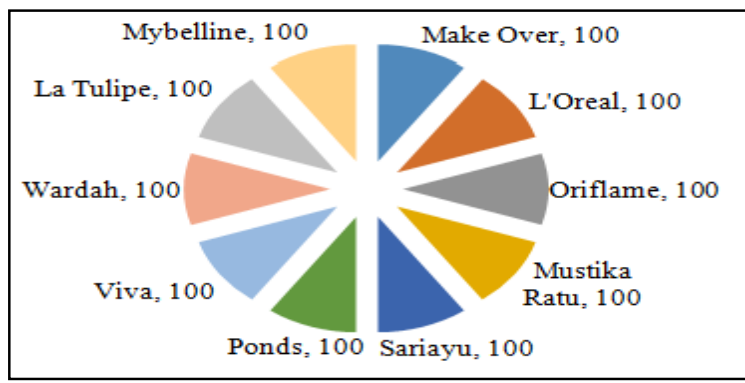

Figure 1 Percentage of students based on gender

So cosmetics manufacturers must create a marketing strategy to find out the target market that must be addressed and know the tastes of consumers.

\section{Dissimilarity Matrix}

From 350 questionnaires, I found it that dissimilarity matrix used was half matrix and diagonally absent that is a dissimilarity matrix symmetrical about the diagonals. We can see the accuracy of the model or object configuration on the perception map in the stress value achieved. 0 (zero) of Stress value shows that the configuration of the object on the perception map has a perfect level of accuracy. So the smaller the stress value achieved, the more precise the configuration of the object got (Dexter, Rollwagen-Bollens, \& Bollens, 2018), (Mair, Borg, \& Rusch, 2016). Following are the stress values achieved by each attribute in the nine cosmetic brands studied: 
Table 1. Stress Value for each Attribute in Cosmetic Brands

\begin{tabular}{|c|c|c|}
\hline Item & Stress Value & Category \\
\hline brand & 0.01425 & perfect \\
\hline packaging & 0.01798 & perfect \\
\hline price & 0.01656 & perfect \\
\hline Ingredients & 0.01343 & perfect \\
\hline
\end{tabular}

From Table 1 it can be seen that the stress value for each attribute in the cosmetics brand studied has a value close to zero, this showed that the model size of each attribute for each cosmetics brand is perfect and the multidimensional scaling solving model is fit.

\section{Multidimensional Scaling Analysis}

Multidimensional Scaling Analysis in this research the aim is to transform the consumer judgments of similarity a brand into distance represented in multidimensional space. By using two dimensions, Multidimensional Scaling processing produces coordinate points of each attribute in the five cosmetic brands that are compared as shown in Figure 2:

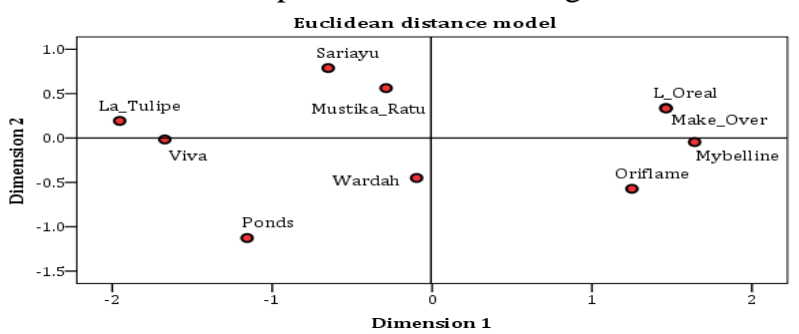

Figure 2 Map positioning output (Brand Popularity)

Figure 2 showed that map the position there are four groups of types of cosmetics in quadrants different. The position of Make Over, L-Oreal, Mybelline, and Oriflame when viewed from the popularity of the four brands gave rise to a positive emotional response to the customers or the four brands were better than other brands of cosmetics. Consumers consider Wardah cosmetics to have similarities with Ponds and Viva, we can see this from the position of the three in the same quadrant. So we can conclude it that Wardah cosmetics compete directly with the two cosmetics. Likewise, the Make Over and L-Oreal are considered having similarities in terms of brand popularity. Found the many cosmetics brands of popular in the market will cause high competition because a familiar product by the public makes these products more and more will be interested be used it, so marketing strategy have to be able maintain by the producer of cosmetics (Make Over, L-Oreal, Mybelline, and Oriflame).

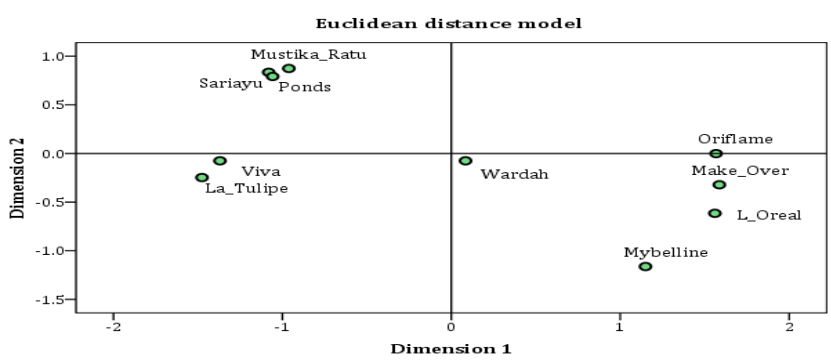

Figure 3 Map positioning output (packaging)

Figure 3 showed that Wardah Cosmetics have little in similarity with others cosmetics on the market, it can be seen from the distance of both them that are far from other cosmetics, so that this cosmetics known as halal labels don't have direct competitors when reviewed in the form of packaging. Oriflame, Make Over, and LOreal cosmetics be considered having similarities in terms of catch of the packaging, so this the three cosmetics competing each other. High competition from the packaging also occurs in MustikaRatu, Sariayu, and Ponds cosmetics.

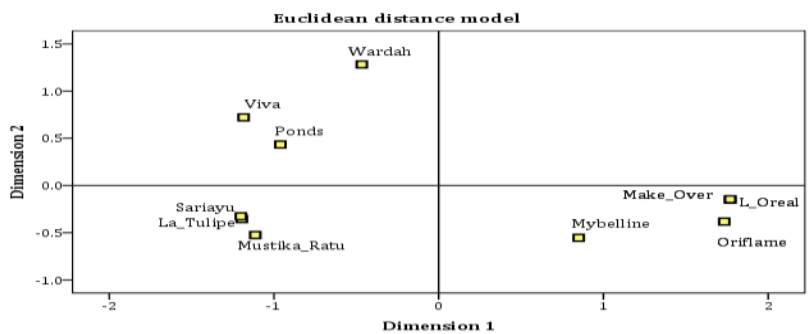

Figure 4 Map positioning output (price)

Figure 4 showed Make Over, L-Oreal, Oriflame, and Mybelline cosmetics are in the same quadrant is on the right side which showed consumers give a positive response to the price of their products. Wardah, Viva, and Ponds cosmetics are similar in price, and Sariayu, La Tulipe and MustikaRatu. The selling price offered by the six cosmetics is cheaper than the Make Over, L-Oreal, Oriflame, and Mybelline cosmetics. We can see this from the sixth position in the left quadrant, but this showed there is a negative response from consumers.

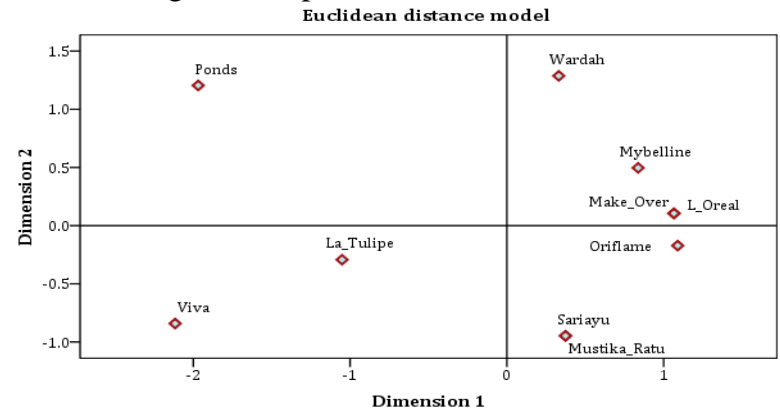

Figure 5 Map positioning output (ingredients) 
Figure 5 showed Wardah, Mybelline, Make Over, L-Oreal, Oriflame, and MustikaRatu Cosmetics in the right quadrant. These six cosmetics get positive responses from consumers when viewed from safe and suitable ingredients for the skin. Whereas Ponds, La Tulipe, and Viva received negative responses from consumers. This means that in terms of safe and suitable ingredients for cosmetic skin Wardah has many competitors in the Market and Wardah's strongest rivals are Mybelline, Make Over, L-Oreal, and Oriflame, because these fourth brands are always superior both in terms of brand popularity, packaging product, and price. The reality on the market, Mybelline, Make Over, LOreal, and Oriflame cosmetic products are more expensive than Wardah, but consumers don't question the product in terms of price so quality is an important consideration for buying a product.

\section{CONCLUSIONS}

Wardah cosmetics are in the positive zone when viewed from packaging and safe material and suitable for the skin, but Wardah is in the negative zone when viewed from brand popularity and price product.

\section{ACKNOWLEDGMENTS}

This study was supported in part by a grant from the P3MP Hamzanwadi University. We also would like to thank SuciMurni for fruitful discussions as well as their support and encouragement.

\section{REFERENCES}

[1] Bai, S., Bai, X., Latecki, L. J., \& Tian, Q. (2016). Multidimensional scaling on multiple input distance matrices. ArXiv Preprint ArXiv:1605.00286.

[2] Borg, I., Groenen, P. J. F., \& Mair, P. (2018). Applied multidimensional scaling and unfolding. Springer.

[3] Brahmbhatt, D., \& Shah, J. (2017). Determinants of Brand Equity from the Consumer's Perspective: A Literature Review. IUP Journal of Brand Management, 14(4).

[4] Couteau, C., \& Coiffard, L. (2016). Overview of skin whitening agents: Drugs and cosmetic products. Cosmetics, 3(3), 27.

[5] de Koeijer, B., Wever, R., \& Henseler, J. (2017). Realizing product-packaging combinations in circular systems: Shaping the research agenda. Packaging Technology and Science, 30(8), 443460.

[6] Dexter, E., Rollwagen-Bollens, G., \& Bollens, S. M. (2018). The trouble with stress: A flexible method for the evaluation of nonmetric multidimensional scaling. Limnology and Oceanography: Methods, 16(7), 434-443.

[7] Elias, A., Gill, R., \& Scharff, C. (2017). Aesthetic labour: Beauty politics in neoliberalism. In Aesthetic labour (pp. 3-49). Springer.

[8] Gengler, C. E., \& Mulvey, M. S. (2017). Planning pre-launch positioning: Segmentation via willingness-to-pay and means-end brand differentiators. Journal of Brand Management, 24(3), 230-249.

[9] Goncharova, N. A., Solosichenko, T. Z., \& Merzlyakova, N. V. (2019). Brand platform as an element of a company marketing strategy. International Journal of Supply Chain Management, 8(4), 815-823.

[10]Huang, S.-L., \& Ku, H.-H. (2016). Brand Image Management For Nonprofit Organizations: Exploring The Relationships Between Websites, Brand Images And Donations. Journal of Electronic Commerce Research, 17(1).

[11] Kemenperin. (2018). Industri Kosmetik Nasional Tumbuh $20 \%$. Retrieved from Kementerian Perindustrian Republik Indonesia website: https://kemenperin.go.id/artikel/18957/IndustriKosmetik-Nasional-Tumbuh-20

[12]Liu, S., Maljovec, D., Wang, B., Bremer, P.-T., \& Pascucci, V. (2016). Visualizing high-dimensional data: Advances in the past decade. IEEE Transactions on Visualization and Computer Graphics, 23(3), 1249-1268.

[13] Mair, P. (2018). Multidimensional scaling. In Modern psychometrics with $R$ (pp. 257-287). Springer.

[14] Mair, P., Borg, I., \& Rusch, T. (2016). Goodnessof-fit assessment in multidimensional scaling and unfolding. Multivariate Behavioral Research, 51(6), 772-789.

[15] Nguyen, L. H., \& Holmes, S. (2019). Ten quick tips for effective dimensionality reduction. PLOS Computational Biology, 15(6), e1006907.

[16] Safford, B., Api, A. M., Barratt, C., Comiskey, D. Ellis, G., McNamara, C., ... Smith, B. (2017). Application of the expanded Creme RIFM consumer exposure model to fragrance ingredients in cosmetic, personal care and air care products. Regulatory Toxicology and Pharmacology, 86, 148-156.

[17] Wyrwa, J., \& Barska, A. (2017). Packaging as a source of information about food products. Procedia Engineering, 182, 770-779. 